\title{
Automated molecular testing of saliva for SARS-CoV-2 detection
}

2 Nancy Matic ${ }^{1,2}$, Tanya Lawson ${ }^{1}$, Gordon Ritchie ${ }^{1,2}$, Aleksandra Stefanovic ${ }^{1,2}$, Victor Leung ${ }^{1,2}$,

3 Sylvie Champagne $e^{1,2}$, Marc G. Romney ${ }^{1,2}$, Christopher F. Lowe $e^{1,2}$

$4 \quad{ }^{1}$ Division of Medical Microbiology and Virology, St. Paul's Hospital, Vancouver, Canada

$5{ }^{2}$ Department of Pathology and Laboratory Medicine, University of British Columbia,

6 Vancouver, Canada

\section{Abstract}

9 With surging global demand for increased SARS-CoV-2 testing capacity, clinical laboratories seek automated, high-throughput molecular solutions, particularly for specimen types which do not rely upon supply of specialized collection devices or viral transport media (VTM). Saliva was evaluated as a diagnostic specimen for SARS-CoV-2 using the cobas ${ }$ SARS-CoV-2 Test on the cobas ${ }^{\circledR} 6800$ instrument. Saliva specimens submitted from various patient populations under investigation for COVID-19 from March-July 2020 were processed in the laboratory with sterile phosphate-buffered saline in a 1:2 dilution and vortexed with glass beads. The processed saliva samples were tested using a commercial assay for detection of the SARS-CoV-2 E gene (LightMix ${ }^{\circledR}$ ) in comparison to the cobas ${ }^{\circledR}$ SARS-CoV-2 Test. 22/64 (34.4\%) of the saliva samples were positive for SARS-CoV-2. Positive and negative concordance between the LightMix ${ }^{\circledR}$ and cobas ${ }^{\circledR}$ assays were $100 \%$. There was no cross-contamination of samples observed on the cobas ${ }^{\circledR} 6800$. The overall invalid rate for saliva on the cobas ${ }^{\circledR} 6800(1 / 128$, $0.78 \%$ ) was similar to the baseline invalid rate observed for nasopharyngeal swabs/VTM and

22 plasma samples. Saliva is a feasible specimen type for SARS-CoV-2 testing on the cobas ${ }^{\circledR}$

236800 , with potential to improve turnaround time and enhance testing capacity. 
medRxiv preprint doi: https://doi.org/10.1101/2020.08.11.20170613; this version posted August 14, 2020. The copyright holder for this preprint (which was not certified by peer review) is the author/funder, who has granted medRxiv a license to display the preprint in perpetuity.

It is made available under a CC-BY 4.0 International license.

\section{Introduction}

25 The global public health response to the COVID-19 pandemic highlighted the critical need for diagnostic testing which is sustainable, practical, rapid and scalable(1). With an increasing

27 worldwide demand for SARS-CoV-2 molecular testing, supply-chain issues for high-quality, flocked nasopharyngeal (NP) swabs have created significant challenges for testing capacity in

29 clinical and public health laboratories. Alternate specimen types, such as saliva, have been reported in some studies to have nearly comparable sensitivity to nasopharyngeal swabs for the

31 detection of SARS-CoV-2, and may be an appropriate supplemental or alternate diagnostic

32 specimen(2-4). Although a variety of methods for saliva collection have been described(2, 5, 6), we have previously shown the utility of testing saliva in the absence of transport media, which enables a simple collection technique that avoids the introduction of potential inhibitors $(7,8)$ and dependence on supply of specialized saliva collection devices.

In addition to potentially obviating supply shortages, saliva has been increasingly described as a useful sample for the diagnosis of COVID-19 to overcome certain pre-analytical collection challenges. Flocked NP swabs have been the preferred specimen type due to established sensitivity, but may occasionally result in false-negative test results due to poor specimen collection quality(9) or timing of testing relative to symptom onset(10-12). Lower respiratory tract specimens such as a bronchoalveolar lavage are often obtained from severely ill patients,

42 but require aerosol-generating medical procedures and thus have the potential for aerosolization 43 and transmission of SARS-CoV-2. Furthermore, only a minority of patients with COVID-19 are 44 able to produce expectorated sputum(13). Saliva is a convenient alternate sample to collect for 
medRxiv preprint doi: https://doi.org/10.1101/2020.08.11.20170613; this version posted August 14, 2020. The copyright holder for this preprint (which was not certified by peer review) is the author/funder, who has granted medRxiv a license to display the preprint in perpetuity.

It is made available under a CC-BY 4.0 International license .

repeatedly negative test results by NP swabs $(14,15)$ or for individuals unwilling or unable to tolerate NP swab collection.

Within our clinical laboratory, processing and testing of saliva is currently a manual process requiring extraction (MagNA Pure Compact or MagNA Pure 96, Roche Molecular Diagnostics, Pleasanton, CA) followed by amplification (LightCycler 480, Roche). Post-analytical reporting

51 into the electronic medical records system is also a manual process. As a result, capacity for

52 saliva testing in our laboratory is limited, with delays in turnaround time compared to nasopharyngeal swabs which are processed entirely on the automated cobas® 6800 (Roche). We

54 sought to evaluate the potential utilization of the cobas ${ }^{\circledR} 6800$ for SARS-CoV-2 detection from 55 saliva.

\section{Materials and Methods}

58 From March-July 2020, saliva was ordered by clinicians from both hospitalized and ambulatory patients for the diagnosis of COVID-19. Briefly, $\geq 1 \mathrm{~mL}$ of saliva was collected in a sterile screw-top container (Starplex Scientific Inc., Etobicoke, Canada) without the addition of

61 transport media, and then processed in the virology laboratory with phosphate-buffered saline

62 (PBS) in a 1:2 dilution and glass beads. Samples were tested using the LightMix® ModularDx

63 SARS-CoV (COVID19) E-gene assay (TIB Molbiol, Berlin, Germany), with use of the MagNA

64 Pure Compact or MagNA Pure 96 and LightCycler 480. The remaining volume of processed

65 saliva samples was stored at $-70^{\circ} \mathrm{C}$. Processed saliva samples were then tested with the cobas ${ }^{\circledR}$

66 SARS-CoV-2 Test (Roche Molecular Diagnostics, Laval, QC) on the cobas® 6800. Prior to

67 cobas ${ }^{\circledR}$ SARS-CoV-2 testing, a software upgrade (Assay Specific Analysis Package [ASAP])

68 was required on the cobas ${ }^{\circledR} 6800$ to prevent viscous specimens from mistakenly being 
medRxiv preprint doi: https://doi.org/10.1101/2020.08.11.20170613; this version posted August 14, 2020. The copyright holder for this preprint (which was not certified by peer review) is the author/funder, who has granted medRxiv a license to display the preprint in perpetuity.

It is made available under a CC-BY 4.0 International license .

69

70

71

72

73

74

75

76

77

78

79

80

81

82

83

84

85

86

\section{Discussion}

88

89

90

\section{Results}

interpreted as clotted/invalid by the instrument. Samples known to be positive for SARS-CoV-2

based on results from the LightMix ${ }^{\circledR}$ assay were alternated with negative samples in a

checkerboard pattern on the 96-well processing plate, and tested in duplicate.

A total of 64 clinical saliva samples were included and tested in duplicate for SARS-CoV-2 on the cobas® 6800 . Twenty-two $(34.4 \%)$ of the samples were known to be positive for SARSCoV-2 based on prior results from the LightMix ${ }^{\circledR}$ assay, and $42(65.6 \%)$ had no detectable SARS-CoV-2. Compared to the LightMix ${ }^{\circledR}$ assay, positive percent agreement and negative percent agreement on the cobas ${ }^{\circledR} 6800$ were $100 \%$. The median cycle threshold $(\mathrm{Ct})$ values for detection of the Envelope (E) gene were comparable between the cobas ${ }^{\circledR} 6800$ (28.82, interquartile range [IQR] 7.29) and the LightMix ® assay (26.63, IQR 7.61) (Figure 1). No carryover or cross-contamination of samples was observed, even with strongly positive samples (Ct values 13 to 24 ) directly adjacent to negative samples. One saliva sample produced an error which was reported by the cobas $6800 \circledR$ instrument as 'Invalid'; this sample was successfully tested on the duplicate run. In total, the observed error rate for saliva samples tested on the cobas® 6800 was $0.78 \%(1 / 128)$.

In our evaluation of the cobas ${ }^{\circledR} 6800$ for saliva testing, we demonstrated complete concordance in comparison to the LightMix ${ }^{\circledR}$ assay, which is the current assay utilized in our laboratory for clinical testing of specimens other than NP swabs such as saliva. 
medRxiv preprint doi: https://doi.org/10.1101/2020.08.11.20170613; this version posted August 14, 2020. The copyright holder for this preprint (which was not certified by peer review) is the author/funder, who has granted medRxiv a license to display the preprint in perpetuity.

It is made available under a CC-BY 4.0 International license .

91 Previous studies have evaluated the feasibility of saliva for SARS-CoV-2 detection on

92 commercial instruments such as the Cepheid GeneXpert® System(16) and cobas® 8800(12).

93 However, there are technical challenges associated with processing saliva for automated, high-

94 throughput testing. As a highly viscous sample compared to viral transport media, there is

95 potential for pipetting errors or instrument contamination. In our laboratory, saliva is pre-

96 processed with sterile PBS and glass beads in order to decrease the viscosity of the sample. The

97 samples utilized in the study were from a variety of clinical situations, including long-term care

98 residents, inpatients at a tertiary care hospital, and outpatient contacts of known COVID-19

99 patients; these samples would be broadly representative of saliva ordered and collected for

100 clinical testing in the future. Reassuringly, testing with this specimen type did not result in a

101 significant number of invalid results $(1 / 128,0.78 \%)$, and was comparable to the rate of invalid

102 results observed in our laboratory from nasopharyngeal swabs with the SARS-CoV-2 Test

$103(0.20 \%)$ and plasma used with other cobas ${ }^{\circledR} 6800$ assays $(0.30 \%)$ (unpublished data). We also

104 assessed the potential for carryover during pipetting on the cobas ${ }^{\circledR}$ by testing positive samples

105 alternated with negative samples in a checkerboard pattern, and did not identify any cross-

106 contamination of samples.

107 This study is limited by the retrospective testing of stored saliva samples. Clinical testing was

108 performed in real time on the LightMix ${ }^{\circledR}$ assay, and samples were stored for subsequent testing

109 on the cobas ${ }^{\circledR}$ after the software had been upgraded. Although testing was not performed in

110 parallel, there was high concordance of testing despite sample storage. Furthermore, testing of

111 retrospective samples was necessary to ensure a sufficient number of saliva samples with

112 detectable SARS-CoV-2 RNA were included. 
medRxiv preprint doi: https://doi.org/10.1101/2020.08.11.20170613; this version posted August 14, 2020. The copyright holder for this preprint (which was not certified by peer review) is the author/funder, who has granted medRxiv a license to display the preprint in perpetuity.

It is made available under a CC-BY 4.0 International license .

113 Due to limited remnant sample volume in some cases, five of the twenty-two saliva samples

114 positive for SARS-CoV-2 (22.7\%) underwent additional dilution with sterile PBS in order to test

115 on the cobas ${ }^{\circledR} 6800$. The $\mathrm{Ct}$ values in these cases cannot be directly compared to those from the

116 LightMix ${ }^{\circledR}$ assay as a measure of assay performance; however, the dilution factor in these cases

117 (1:3 to 1:5) would have had a negligible effect on the $\mathrm{Ct}$ values, and the aim of this study was to

118 assess the technical feasibility of saliva samples for automated, high-throughput SARS-CoV-2

119 testing on the cobas ${ }^{\circledR} 6800$.

120 Transitioning to an automated platform for saliva testing is critical for enhancing SARS-CoV-2

121 testing capacity, particularly in preparation for a potential resurgence of COVID-19 cases or

122 mass testing of defined populations. Automated testing reduces errors in the pre-analytical and

123 post-analytical phases, and improves turnaround time by enabling saliva to be processed on

124 multiple runs per day (including overnight testing). Our evaluation confirmed the feasibility of

125 saliva as a suitable specimen type for SARS-CoV-2 testing on the cobas@ 6800 platform.

\section{Acknowledgements}

128 We are grateful to our medical laboratory technologists who are highly committed to patient care

129 and laboratory quality improvement.

130 This study was supported by Roche Diagnostics for a software upgrade of the cobas® 6800 , but

131 no financial compensation was provided. Roche Diagnostics was not involved in the study

132 design, implementation nor analysis of the data.

133 This study received approval from the Providence Health Care Research Ethics Board.

\section{Potential Conflicts of Interest}


medRxiv preprint doi: https://doi.org/10.1101/2020.08.11.20170613; this version posted August 14, 2020. The copyright holder for this preprint (which was not certified by peer review) is the author/funder, who has granted medRxiv a license to display the preprint in perpetuity.

It is made available under a CC-BY 4.0 International license .

136

137

138

139

140

141

142

143

144

145

146

147

148

149

150

151

152

153

154

155

156

157

158

N.M. reports honoraria related to speaker engagement outside the submitted work for Roche

Molecular Systems, Inc. All other authors report no relevant conflicts of interest.

\section{References}

1. (WHO) WHO. 2020. Laboratory testing for 2019 novel coronavirus (2019-nCoV) in suspected human cases.

2. To KKW, Tsang OTY, Leung WS, Tam AR, Wu TC, Lung DC, Yip CCY, Cai JP, Chan JMC, Chik TSH, Lau DPL, Choi CYC, Chen LL, Chan WM, Chan KH, Ip JD, Ng ACK, Poon RWS, Luo CT, Cheng VCC, Chan JFW, Hung IFN, Chen Z, Chen H, Yuen KY. 2020. Temporal profiles of viral load in posterior oropharyngeal saliva samples and serum antibody responses during infection by SARS-CoV-2: an observational cohort study. Lancet Infect Dis 3099:1-10.

3. Jamal AJ, Mozafarihashjin M, Coomes E, Powis J, Li AX, Paterson A, Anceva-Sami S, Barati S, Crowl G, Faheem A, Farooqi L, Khan S, Prost K, Poutanen S, Taylor M, Yip L, Zhong XZ, McGeer AJ, Mubareka S. 2020. Sensitivity of nasopharyngeal swabs and saliva for the detection of severe acute respiratory syndrome coronavirus 2 (SARS-CoV2). Clin Infect Dis 27:9-11.

4. Williams E, Bond K, Zhang B, Putland M, Williamson DA. 2020. Saliva as a noninvasive specimen for detection of SARS-CoV-2. J Clin Microbiol 50.

5. Wyllie AL, Fournier J, Casanovas-Massana A, Campbell M, Tokuyama M, Vijayakumar P, Geng B, Muenker MC, Moore AJ, Vogels CBF, Petrone ME, Ott IM, Lu P, LuCulligan A, Klein J, Venkataraman A, Earnest R, Simonov M, Datta R, Handoko R, Naushad N, Sewanan LR, Valdez J, White EB, Lapidus S, Kalinich CC, Jiang X, Kim DJ, 
medRxiv preprint doi: https://doi.org/10.1101/2020.08.11.20170613; this version posted August 14, 2020. The copyright holder for this preprint (which was not certified by peer review) is the author/funder, who has granted medRxiv a license to display the preprint in perpetuity.

It is made available under a CC-BY 4.0 International license.

Kudo E, Linehan M, Mao T, Moriyama M, Oh JE, Park A, Silva J, Song E, Takahashi T, Taura M, Weizman O-E, Wong P, Yang Y, Bermejo S, Odio C, Omer SB, Cruz CS Dela, Farhadian S, Martinello RA, Iwasaki A, Grubaugh ND, Ko AI. 2020. Saliva is more sensitive for SARS-CoV-2 detection in COVID-19 patients than nasopharyngeal swabs. medRxiv 2020.04.16.20067835.

6. Azzi L, Carcano G, Gianfagna F, Grossi P, Gasperina DD, Genoni A, Fasano M, Sessa F, Tettamanti L, Carinci F, Maurino V, Agostino R, Tagliabue A, Baj A. 2020. SALIVA IS A RELIABLE TOOL TO DETECT SARS-CoV-2. J Infect 1-6.

7. Rodríguez A, Vaneechoutte M. 2019. Comparison of the efficiency of different cell lysis methods and different commercial methods for RNA extraction from Candida albicans stored in RNAlater. BMC Microbiol 19:1-10.

8. Jiang L, Li L, Kang P, Yu H, Nie SP, Xie MY, Gong J. 2019. Inappropriateness of RNAlater to preserve Caenorhabditis elegans for RNA extraction. MethodsX 6:2460_ 2467.

9. Kinloch N, Ritchie G, Brumme CJ, Dong W, Dong W, Lawson T, Jones RB, Montaner JSG, Leung V, Romney MG, Stefanovic A, Matic N, Lowe CF BZ. 2020. Suboptimal biological sampling as a probable cause of false-negative COVID-19 diagnostic test results. J Infect Dis 1-4.

10. Wölfel R, Corman VM, Guggemos W, Seilmaier M, Zange S, Müller MA, Niemeyer D, Jones TC, Vollmar P, Rothe C, Hoelscher M, Bleicker T, Brünink S, Schneider J, Ehmann R, Zwirglmaier K, Drosten C, Wendtner C. 2020. Virological assessment of hospitalized patients with COVID-2019. Nature 1-14.

11. He X, Lau EHY, Wu P, Deng X, Wang J, Hao X, Lau YC, Wong JY, Guan Y, Tan X, Mo 
medRxiv preprint doi: https://doi.org/10.1101/2020.08.11.20170613; this version posted August 14, 2020. The copyright holder for this preprint (which was not certified by peer review) is the author/funder, who has granted medRxiv a license to display the preprint in perpetuity.

It is made available under a CC-BY 4.0 International license .

X, Chen Y, Liao B, Chen W, Hu F, Zhang Q, Zhong M, Wu Y, Zhao L, Zhang F, Cowling BJ, Li F, Leung GM. 2020. Temporal dynamics in viral shedding and transmissibility of COVID-19. Nat Med 26:672-675.

12. Nagura-Ikeda M, Imai K, Tabata S, Miyoshi K, Murahara N, Mizuno T, Horiuchi M, Kato K, Imoto Y, Iwata M, Mimura S, Ito T, Tamura K, Kato Y. 2020. Clinical evaluation of self-collected saliva by RT-qPCR, direct RT-qPCR, RT-LAMP, and a rapid antigen test to diagnose COVID-19. J Clin Microbiol.

13. Huang C, Wang Y, Li Z, Ren L, Zhao J, Hu Y, Zhang L, Fan G, Xu J, Gu X, Cheng Z, Yu T, Xia J, Wei Y, Wu W, Xie X, Yin W, Li H, Liu M, Xiao Y, Hao H, Guo L, Xie J, Wang G, Jiang R, Gao Z, Hin Q, Wang J CB. 2020. Since January 2020 Elsevier has created a COVID-19 resource centre with free information in English and Mandarin on the novel coronavirus COVID- research that is available on the COVID-19 resource centre including this ScienceDirect Clinical characteris. Lancet 395:497-506.

14. Koven S. 2020. Engla, Journal - 2010 - New engla nd journal. N Engl J Med 38:1-2.

15. Watson J, Whiting PF, Brush JE. 2020. Interpreting a covid-19 test result. BMJ 369:1-7.

16. McCormick-Baw C, Morgan K, Gaffney D, Cazares Y, Jaworski K, Byrd A, Molberg K, Cavuoti D. 2020. Saliva as an Alternate Specimen Source for Detection of SARS-CoV-2 in Symptomatic Patients Using Cepheid Xpert Xpress SARS-CoV-2. J Clin Microbiol $58: 2-3$. 


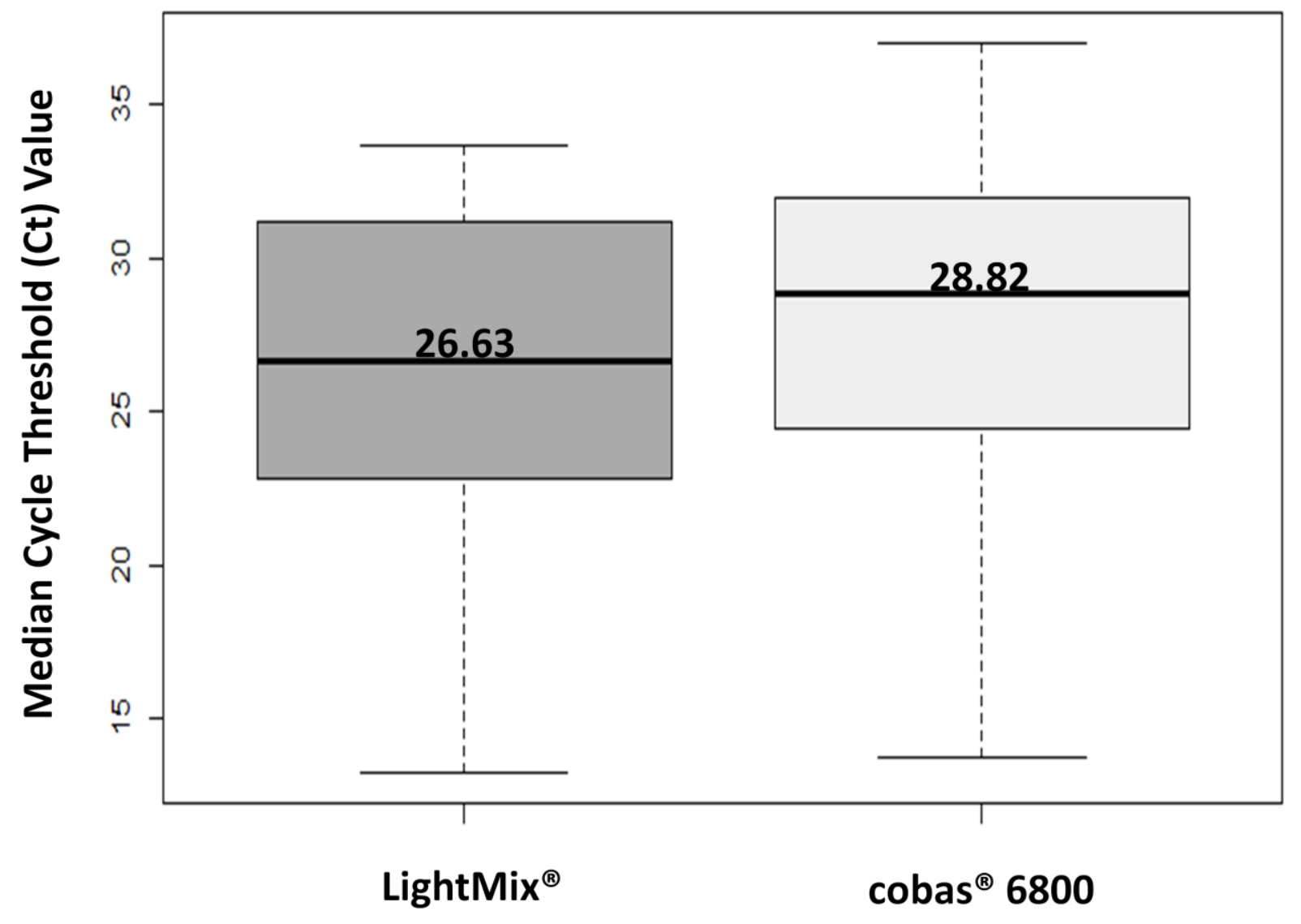

206 Figure 1: No significant difference in median cycle threshold $(\mathrm{Ct})$ values for the Envelope $(\mathrm{E})$

207 gene was observed in saliva samples positive for SARS-CoV-2, using the LightMix ${ }^{\circledR}$

208 ModularDx SARS-CoV (COVID19) E-gene assay (TIB Molbiol, Berlin, Germany) and the

209 cobas ${ }^{\circledR}$ SARS-CoV-2 Test (Roche Molecular Diagnostics, Laval, QC) on the cobas® 6800

210 platform. 